\title{
Pertumbuhan Widelia (Wedelia trilobata (L) Hitchc) pada Tingkat Naungan Berbeda di Jalur Hijau Kota Yogyakarta
}

\section{(Widelia (Wedelia trilobata (L) Hitchc) Growth at Different Shading Levels in the Roadside Greenery of Yogyakarta City)}

\author{
Dewi Maimunah, Siti Nurul Rofiqo Irwan*, Didik Indradewa
}

(Diterima Desember 2019/Disetujui Juni 2020)

\begin{abstract}
ABSTRAK
Tanaman widelia (Wedelia trilobata (L) Hitchc) merupakan herba menjalar dari famili Asteraseae yang berpotensi sebagai tanaman penutup tanah di jalur hijau jalan. Tanaman ini mudah tumbuh, memiliki nilai estetika, baik daun maupun bunga. Penelitian ini bertujuan untuk mengamati iklim mikro jalur hijau jalan dan mengkaji pertumbuhan vegetatif widelia pada tiga tingkat naungan kanopi pohon di jalan kolektor dan jalan lokal Kota Yogyakarta. Penelitian dilaksanakan dengan menggunakan rancangan antarlokasi (oversite) yang terdiri atas dua faktor, yaitu faktor jalan (jalan kolektor dan jalan lokal) dan faktor tingkat naungan kanopi pohon (penuh $>50 \%$, sedang $20-50 \%$, dan tanpa naungan/terbuka $0 \%$ ). Hasil analisis ragam tidak menunjukkan perbedaan nyata pada iklim mikro dan pada parameter pertumbuhan widelia di jalan kolektor maupun di jalan lokal. Di jalan kolektor, kecepatan angin, kebisingan, dan jumlah kendaraan menunjukkan angka yang lebih tinggi dibandingkan dengan di jalan lokal. Hasil analisis ragam di tiga tingkat naungan pohon menunjukkan perbedaan nyata pada iklim mikro dan parameter pertumbuhan widelia, yaitu intensitas cahaya, suhu udara, kelembapan udara, suhu tanah, lengas tanah, panjang stolon, jumlah daun, jumlah tunas, jumlah ruas, dan bobot kering tanaman, di mana nilai terendah ditemukan pada tingkat naungan penuh $(>50 \%)$. Semua variabel pengamatan tidak menunjukkan interaksi nyata antara dua jenis jalan dan tiga tingkat naungan kanopi pohon.
\end{abstract}

Kata kunci: iklim mikro, jalur hijau jalan, naungan kanopi pohon, widelia (Wedelia trilobata (L) Hitchc), Yogyakarta

\section{ABSTRACT}

Widelia plant (Wedelia trilobata (L) Hitchc) is a spreading herb from the Asterase family that potentially can be used as a ground cover in the roadside greenery because this plant has a faster growing rate and has aesthetic values in both leaves and flowers. The aim of this study was to observe the microclimate of the roadside greenery and the vegetative growth of widelia at three levels of the tree canopy shades in the collector and local roads of Yogyakarta City. The experiment was carried out using an inter-site design (oversite) consisting of two factors, namely road factors (collector roads and local roads) and levels of shade canopy (full $>50 \%$, moderate $20-50 \%$ and no shade $0 \%$ ). The results of the analysis of variance did not show any significant differences on the microclimate and widelia growth parameters on the collector or local roads. The wind speed, noise, and number of vehicles on the collector road showed the higher number compared to those on the local road. The results of analysis of variance in the three levels of tree canopy shade also showed significant differences in microclimate and widelia growth parameters. The lowest light intensity, air temperature, humidity, soil temperature, soil moisture, stolon length, number of leaves, number of shoots, number of segments, and dry weight plants were found in full shade level (> $50 \%$ ). All observation variables did not show any significant interaction effect between the two types of roads and the three levels of tree shades.

Keywords: canopy shade, microclimate, roadside greenery, widelia (Wedelia trilobata (L) Hitchc), Yogyakarta

\section{PENDAHULUAN}

Jalur hijau merupakan bagian dari ruang terbuka hijau perkotaan yang berfungsi sebagai peneduh, penyerap polusi udara, peredam kebisingan, pemecah angin, pembatas pandang, dan penahan silau lampu kendaraan. Tanaman yang dibudidayakan pun bervariasi, mulai dari tanaman berhabitus tinggi, seperti

Departemen Agronomi, Fakultas Pertanian, Universitas Gadjah mada, JL. Flora, Bulaksumur, Kabupaten Sleman, Daerah Istimewa Yogyakarta 55281

* Penulis Korespondensi: Email: rofiqoirwan@ugm.ac.id pohon, dan tanaman berhabitus rendah, seperti tanaman perdu, semak, atau rumput. Widelia (Wedelia trilobata (L) Hitchc.) merupakan tanaman penutup tanah berupa semak berbunga kuning, tajuk daun lebat, dan menjalar dari famili Asteraceae (Gambar 1). Tanaman ini berpotensi sebagai tanaman jalur hijau karena tumbuhan ini telah dimanfaatkan sebagai tanaman penutup tanah dan tanaman hias di jalan kota di Singapura (Singapura Government 2018).

Tanaman berhabitus tinggi umumnya memberikan efek naungan pada tanaman berhabitus rendah, namun persentase efek naungan yang diberikan tidak sama (Wahyunah et al. 2016) bergantung pada jenis 


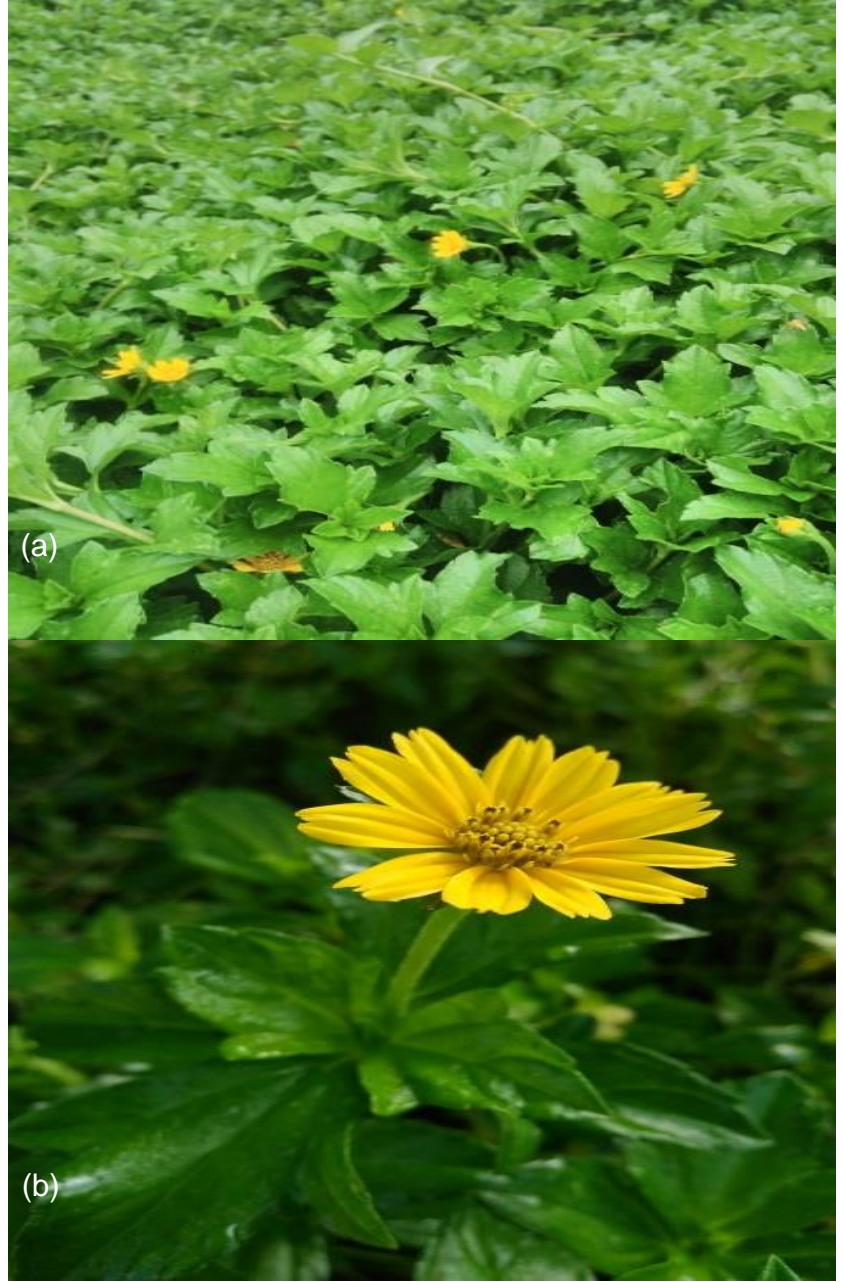

Gambar 1 Widelia (Wedelia Trilobata (L.) Hitchc. a) Rumpun widelia dan b) Bunga widelia.

tanaman, bentuk kanopi, dan biomassa daun (Buyadi et al. 2013; Wahyunah et al. 2016; Sadoudi et al. 2018). Respons pertumbuhan tanaman berhabitus rendah di bawah naungan bervariasi. Miswati (2017) menyatakan bahwa pertumbuhan tanaman kumis kucing (Orthisiphon stamineus Benth.) mengalami penurunan pada tingkat naungan 40 , 60, dan $80 \%$. Respons pertumbuhan tersebut membuktikan bahwa tanaman kumis kucing tidak tahan terhadap naungan. Berbeda dari tanaman widelia berdasar pernyataan $\mathrm{Si}$ et al. (2014) yang menyatakan bahwa tumbuhan widelia dengan naungan dan tanpa naungan menunjukkan pertumbuhan yang sama baiknya.

Tanaman jalur hijau perkotaan umumnya toleran terhadap paparan polusi udara serta memiliki fungsi untuk menyerap ataupun menjerap polutan. Peningkatan jumlah penduduk mengakibatkan peningkatan jumlah kendaraan bermotor di Kota Yogyakarta (BPS 2018). Hal tersebut mengakibatkan peningkatan polusi udara di lingkungan kota. Akan tetapi, peningkatan tersebut masih berada di bawah ambang batas pencemaran polusi udara (BLH 2018). Polusi yang disumbangkan oleh kendaraan bermotor dapat berupa gas dan/atau partikel. Saleha et al. (2013) mengungkapkan bahwa widelia dapat menyerap polutan timbal
$(\mathrm{Pb})$ yang dibuktikan dengan kandungan timbal yang terdeteksi dalam jaringan akar, batang, dan daun. Pernyataan tersebut mengungkapkan bahwa widelia memiliki salah satu kriteria dari fungsi ruang terbuka hijau dan berpotensi sebagai tanaman jalur hijau. Selain paparan polusi udara, tanaman juga terpengaruh oleh kebisingan yang disebabkan oleh kendaraan bermotor ataupun aktivitas lainnya.

Polusi udara dan kebisingan di setiap jenis jalan kemungkinan berbeda. Perbedaan tersebut diduga karena perbedaan dalam jumlah dan jenis kendaraan yang melintas. Berdasarkan Peraturan Pemerintah RI No. 34 tahun 2006 tentang jalan, jalan terdiri atas beberapa jenis dengan kriteria jenis kendaraan serta kecepatan kendaraan yang berbeda. Jalan kolektor dan jalan lokal merupakan dua di antara jenis jalan perkotaan. Jalan kolektor merupakan jalur utama aktivitas kendaraan yang menghubungkan lokasi satu dengan lokasi lainnya. Umumnya, jenis kendaraan yang melintasi tidak hanya kendaraan pribadi saja, namun kendaraan umum atau kendaraan angkutan lainnya dengan kecepatan minimum 20-40 km.jam ${ }^{-1}$. Sementara itu, jalan lokal merupakan jalan permukiman yang pada umumnya kendaraan yang melintasi adalah kendaraan pribadi dengan kecepatan minimum $10-20 \mathrm{~km} . j a m^{-1}$ dan jalan ini bukan merupakan jalan utama kota (Peraturan Pemerintah RI No. 34 2006). Perbedaan kedua jenis jalan dan tingkat naungan kemungkinan besar memengaruhi iklim mikro di sekitar tanaman yang dapat memengaruhi pertumbuhan dan perkembangan tanaman. Penelitian ini bertujuan untuk mengetahui pertumbuhan widelia pada tingkat naungan yang berbeda di jalan kolektor dan jalan lokal Kota Yogyakarta.

\section{METODE PENELITIAN}

Percobaan dilaksanakan pada bulan Januari-April 2019 di jalur hijau jalan kolektor dan jalan lokal, Kecamatan Gondokusuman, Kota Yogyakarta, Daerah Istimewa Yogyakarta (Gambar 2). Analisis sampel tanaman dilakukan di Laboratorium IImu Tanaman, Laboratorium Produksi, Laboratorium Hortikultura, Fakultas Pertanian dan Laboratorium Biologi, Fakultas Biologi, Universitas Gadjah Mada, Yogyakarta.

Percobaan dilaksanakan menggunakan pot keranjang dengan rancangan antarlokasi (oversite) yang terdiri atas dua faktor. Faktor pertama adalah jenis jalan yang terdiri atas 2 aras, yaitu K: Jalan kolektor (terletak di jalur hijau Jl. Affandi, Jl. Laksda Adisudjipto, JI.Urip Sumoharjo, dan Jl. Jend Sudirman) dan L : Jalan lokal (terletak di jalur hijau Jl. S. Ratulangi, JI. Dewi Sartika, Jl.Kartini, Jl. Candrakirana, dan Jl. Sagan). Faktor kedua adalah tingkat naungan kanopi pohon yang terdiri atas 3 aras, yaitu: $\mathrm{N}_{1}$ : Naungan kanopi pebuh ( $>50 \%$ ); $\mathrm{N}_{2}$ : Naungan kanopi sedang $(20-49 \%)$, dan $\mathrm{N}_{3}$ : Tanpa naungan kanopi $(0 \%)$. Setiap kombinasi perlakuan diulang sebanyak 3 kali. 


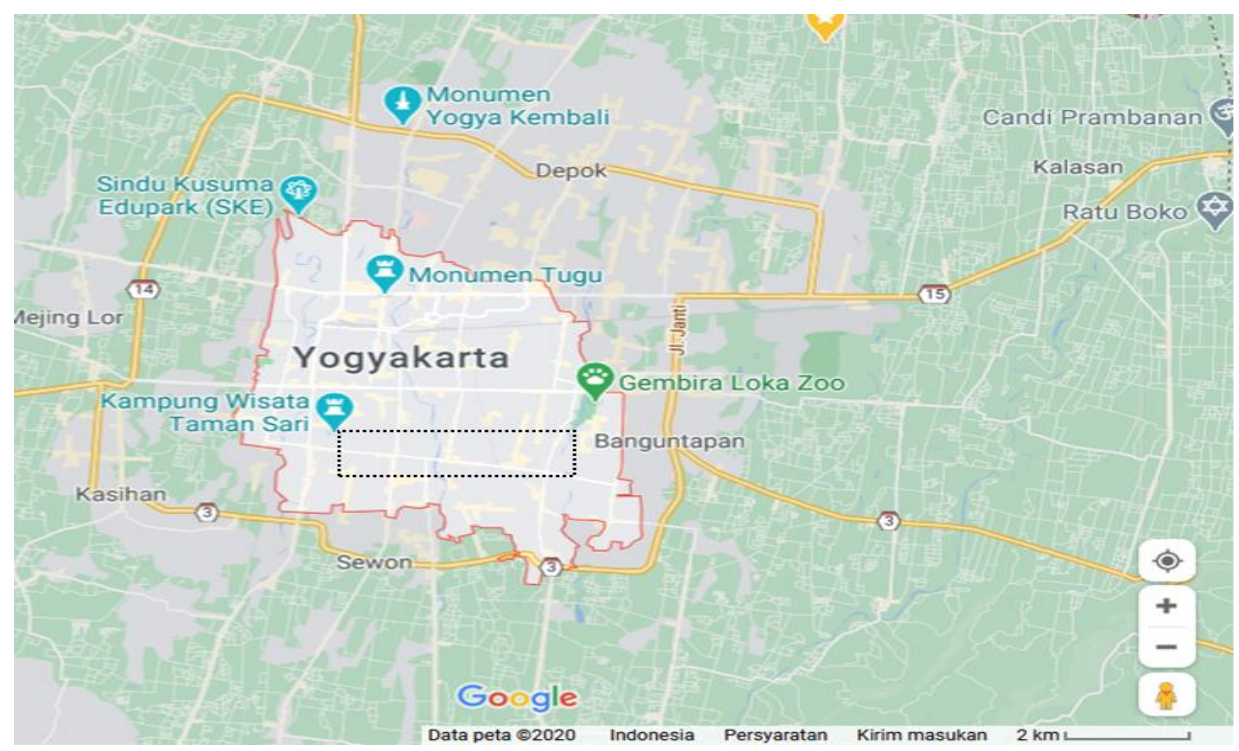

Gambar 2. Lokasi Penelitian di Kecamatan Gondokusuman, Kota Yogyakarta, Daerah Istimewa Yogyakarta.

Penanaman menggunakan media tanam yang sesuai dengan standar operasional Badan Lingkungan Hidup Kota Yogyakarta. Perbandingan antara tanah dan pupuk kandang sebagai media tanam yang digunakan adalah 1:1. Media yang telah siap dimasukkan ke dalam pot keranjang berukuran $47 \times 33 \times 16 \mathrm{~cm}$ sebagai tempat media tanam, kemudian disiram agar tanah lembap. Stek widelia yang berasal dari sulursulur widelia digunakan sebagai bahan tanam. Sulur tersebut berasal dari tumbuhan liar di lingkungan Kelurahan Maguoharjo, Daerah Istimewa Yogyakarta. Sulur dipotong 5-10 cm dengan satu mata tunas.

Batang widelia berwarna hijau-cokelat, berbentuk bulat yang terdiri atas ruas-ruas yang memiliki akar di setiap buku yang menyentuh tanah. Pada beberapa buku akan tumbuh tunas dan membentuk ramet. Daun widelia sedikit tebal berwarna hijau berhadapan (oposite), tidak memiliki tangkai (daun tidak lengkap), tepi daun bergerigi, dan permukaan daun berbulu (CTAHR 1997; Thaman 1999; Gilman 1999). Bunga widelia berwarna kuning cerah berukuran kecil dan bertangkai yang terdiri atas dua macam bunga, yaitu bunga tabung (flos discl) dan bunga pita (flos ligullatus). Calon bunga muncul di setiap ramet. Bagian-bagian widelia ditunjukkan Gambar 3.

Stek widelia ditanam dengan jarak $20 \times 20 \mathrm{~cm}$ dalam pot keranjang (Gambar 4). Kemudian bibit dirawat di lokasi yang homogen selama satu bulan, setelah itu keranjang bibit dipindahkan ke lokasi perlakuan, yaitu jalan kolektor dan jalan lokal pada tiga tingkat naungan yang ber-beda.

Parameter lingkungan atau iklim mikro diukur setiap dua minggu sekali pada pagi (06:00-07:00 WIB), siang (12:00-13:00 WIB), dan sore (17:00-18:00 WIB). Parameter yang diukur adalah intensitas cahaya menggunakan LUX meter, suhu udara, dan kelembapan udara menggunakan termohidrometer, suhu tanah menggunakan termometer tanah, dan lengas tanah. Karena lokasi percobaan merupakan jalur hijau kota maka diamati jumlah kendaraan menggunakan

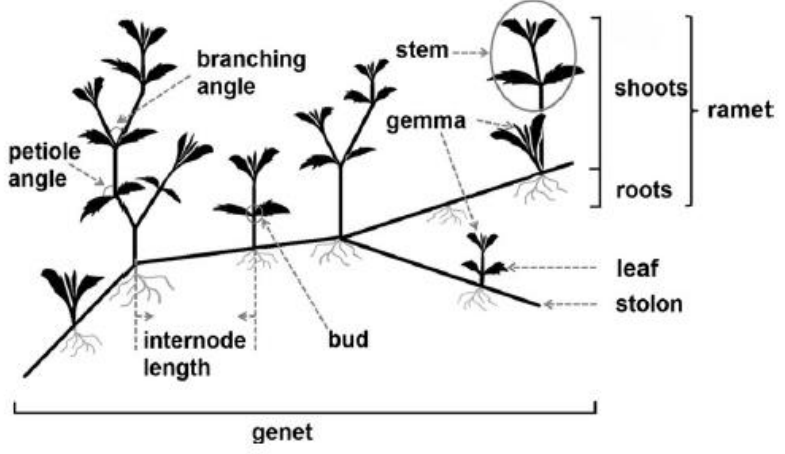

Gambar 3 Bagian-bagian widelia (Wedelia trilobata (L) Hitchc) (Si et al. 2014).

hand counter, kebisingan menggunakan sound meter, dan kecepatan angin menggunakan anemometer.

Parameter pertumbuhan tanaman widelia diukur setiap satu minggu sekali, yaitu panjang stolon, jumlah daun, jumlah ruas, dan jumlah tunas. Panjang stolon diukur mulai dari pangkal stolon hingga pucuk dengan menggunakan meteran, sedangkan jumlah daun, jumlah ruas, dan jumlah tunas dihitung menggunakan hand counter. Pengukuran bobot kering total dan indeks luas daun dilakukan sebanyak 2 kali pada saat tamanan berumur 6 dan 12 minggu setelah pindah tanam secara destruktif. Bobot kering total diukur dengan cara mengeringkan tanaman menggunakan oven sampai bobot kering konstan dan indeks luas daun diukur menggunakan leaf area meter. Analisis pertumbuhan yang diukur adalah bobot daun khas, laju asimilasi bersih, dan laju pertumbuhan nisbi. Data yang diperoleh dari hasil pengamatan dianalisis dengan sidik ragam (ANOVA). Jika terdapat beda nyata maka dilakukan uji lanjut Duncan's Multiple Range Test (DMRT) pada taraf $5 \%$.

Berikut rumus analisis pertumbuhan menurut Gradner et al. (1991): 
Bobot daun khas $(\mathrm{BDK})=\frac{\mathrm{lw}}{\mathrm{la}} \cdot\left(\mathrm{cm}^{2} \cdot \mathrm{g}^{-1}\right)(1)$

Laju asimilasi bersih (LAB) $=\frac{\mathrm{W} 2-\mathrm{W} 1}{\mathrm{~T} 2-\mathrm{T} 1} \times \frac{\ln \mathrm{La} 2-\ln \mathrm{La} 1}{\mathrm{La} 2-\mathrm{La} 1}$ $\left(\right.$ g. $\left.\mathrm{dm}^{2} \cdot \mathrm{ming}^{-1}\right)(2)$

Laju pertumbuhan nisbi $(\mathrm{LPN})=\frac{\ln \mathrm{W} 2-\ln \mathrm{W} 1}{\mathrm{~T} 2-\mathrm{T} 1}$ $\left(g^{-1} \cdot g^{-1} \cdot \operatorname{ming}^{-1}\right)(3)$

Keterangan:

$\mathrm{W}_{1}$ = Bobot kering total tanaman waktu 1

$\mathrm{W}_{2}=$ Bobot kering total tanaman waktu 2

$\mathrm{T}_{1}=$ Waktu pengamatan sampel 1

$\mathrm{T}_{2}=$ Waktu pengamatan sampel 2

La = Luas daun

$L w=$ Bobot kering daun

\section{HASIL DAN PEMBAHASAN}

\section{Kondisi lingkungan percobaan}

Kondisi lingkungan merupakan salah satu faktor yang berpengaruh pada pertumbuhan tanaman. Gambar 5 menunjukkan contoh kondisi jalan kolektor dan jalan lokal lokasi penelitian. Pada Tabel 1 menunjukkan hasil analisis ragam kondisi lingkungan atau iklim mikro, yaitu rata-rata intensitas cahaya, suhu udara, kelembapan udara, suhu tanah, dan kadar lengas tanah di jalan kolektor dan di jalan lokal tidak menunjukkan perbedaan nyata. Hal ini menunjukkan bahwa jalan kolektor dan jalan lokal memiliki kondisi iklim mikro yang relatif sama, berbeda dari hasil analisis ragam iklim mikro pada tiga tingkat naungan. Variabel intensitas cahaya, suhu udara, dan suhu tanah pada naungan kanopi penuh $(>50 \%)$, sedang (20-50\%), dan tanpa naungan/terbuka (0\%). Kelembapan udara dan kadar lengas tanah tidak menunjukkan perbedaan nyata pada perbedaan tingkat naungan ini. Hendriawan et al. (2016) juga menyatakan hasil yang sama pada kondisi iklim mikro dengan naungan ataupun tanpa naungan. Intensitas cahaya pada tingkat naungan kanopi tanpa naungan/terbuka (0\%) adalah 20289,77 lux, lebih tinggi dibandingkan dengan intensitas cahaya pada tingkat naungan kanopi penuh (>50\%) dan sedang (20-50\%). Nilai rata-rata intensitas cahaya pada tingkat naungan kanopi pohon penuh (>50\%) paling rendah adalah 3095,59 lux.

Pada area naungan kanopi pohon penuh (>50\%) menunjukkan rerata suhu udara $30,70^{\circ} \mathrm{C}$ dan suhu tanah $26,20^{\circ} \mathrm{C}$, yang lebih rendah dibandingkan dengan suhu udara dan suhu tanah di tingkat naungan kanopi pohon sedang (20-50\%) dan tanpa naungan/

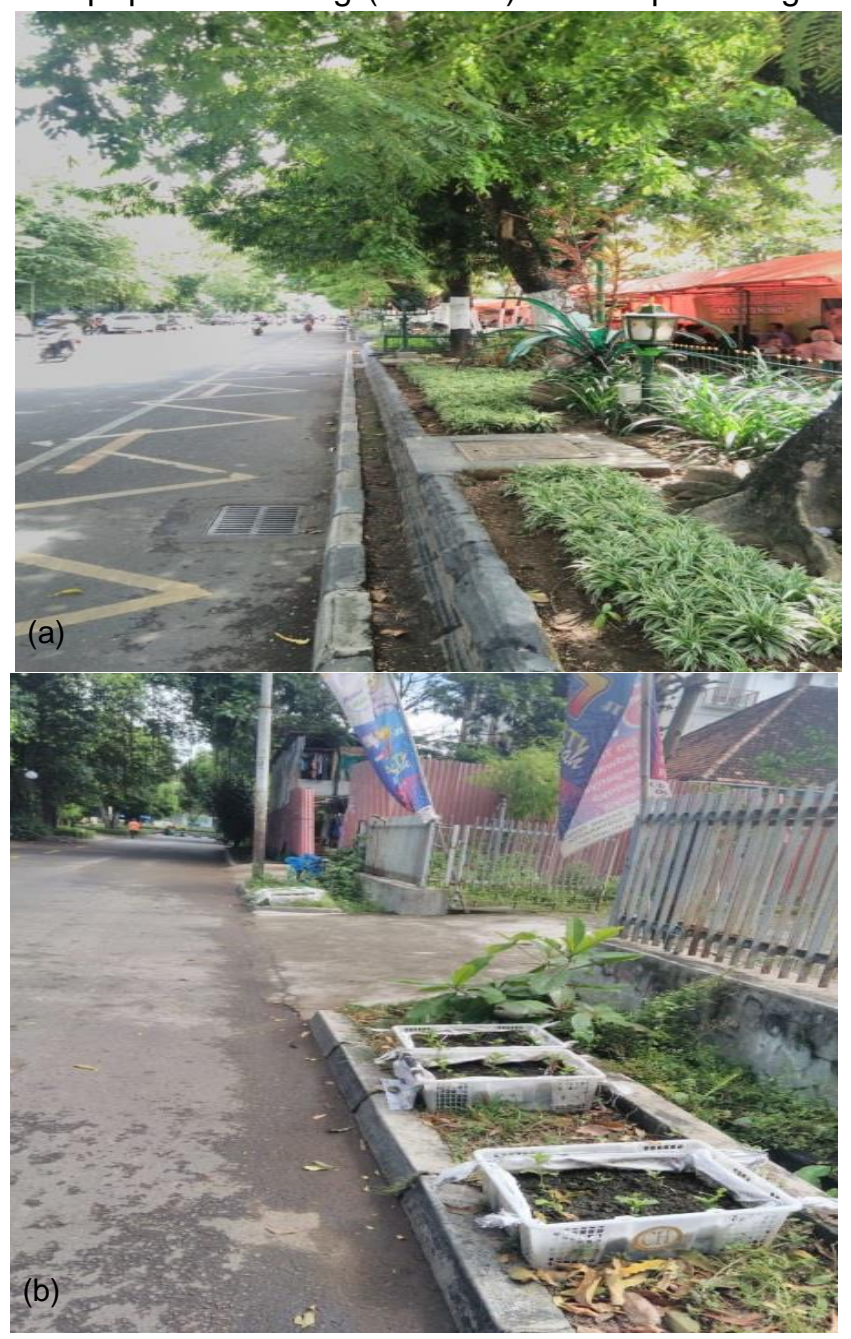

Gambar 5 a) Kondisi jalan kolektor dan b) Jalan lokal.

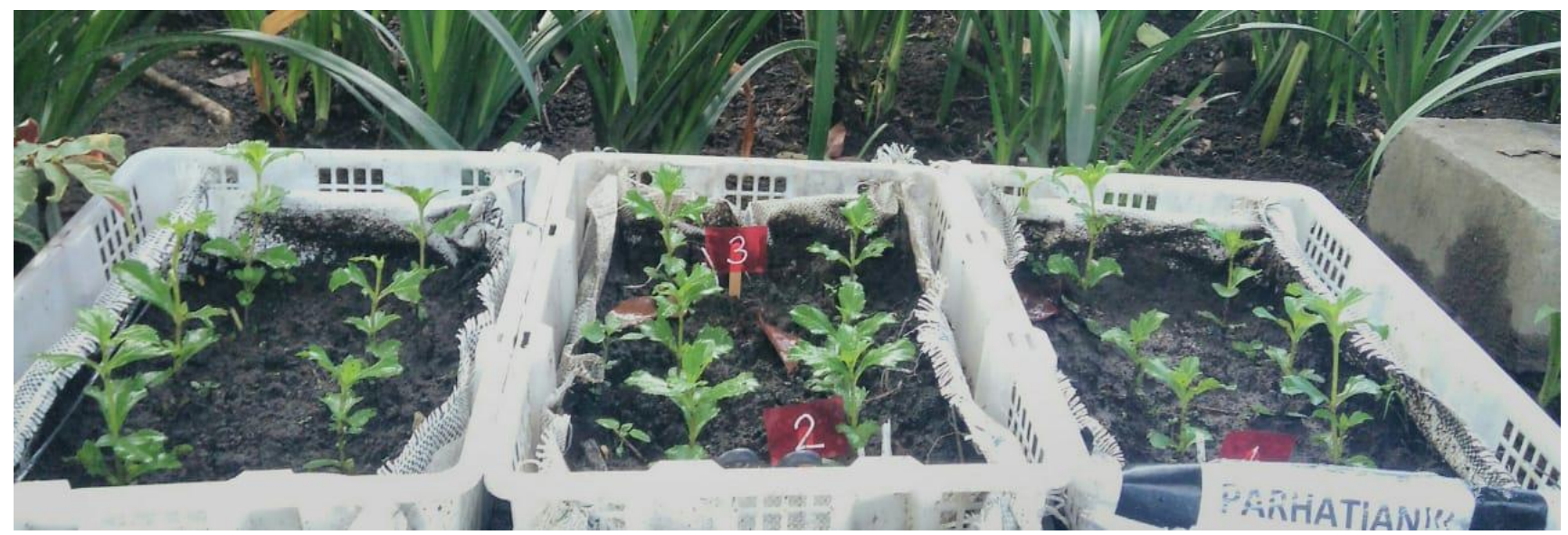

Gambar 4 Foto tanaman saat pindah ke lokasi percobaan. 
terbuka (0\%). Hasil analisis ragam menunjukkan bahwa pada tingkat naungan kanopi pohon sedang (20-50\%) dan tanpa naungan/terbuka $(0 \%)$ memberikan pengaruh yang sama pada suhu udara lingkungan, yang berbeda dari hasil analisis ragam suhu tanah pada tingkat naungan kanopi pohon sedang (20$50 \%)$ dan tanpa naungan/terbuka (0\%). Du et al. (2017) menyatakan bahwa vegetasi memiliki peran dalam penurunan suhu udara sekitar.

Gambar 6 menunjukkan hubungan antara intensitas cahaya dan variabel suhu udara (A), kelembapan udara (B), suhu tanah (C), dan kadar lengas tanah (D). Intensitas cahaya memiliki hubungan linear positif dengan varibel-variabel tersebut. Semakin tinggi intensitas cahaya maka semakin tinggi suhu udara lingkungan, semakin rendah kelembapan udara, semakin tinggi suhu tanah, dan semakin turun kadar lengas tanah.
Berdasarkan hasil analisis ragam pada Tabel 1, rata-rata jumlah kendaraan yang melintasi jalan kolektor dan jalan lokal menunjukkan perbedaan yang sangat nyata. Data kendaraan melintas tertinggi ditemukan di jalan kolektor dengan rata-rata 65 unit.menit ${ }^{-1}$ dan terendah ditemukan di jalan lokal dengan rata-rata 5 unit.menit ${ }^{-1}$. Jumlah kendaraan yang melintas akan memengaruhi tingkat kebisingan dan kecepatan angin di jalur hijau jalan. Kebisingan tertinggi $(74,32 \mathrm{~dB})$ ditemukan di jalan kolektor dan terendah $(62,02 \mathrm{~dB})$ ditemukan di jalan lokal. Di dua jenis jalan ini ditemukan tingkat kebisingan yang cukup tinggi. Berdasarkan KEP-48/MENLH/11/1996 standar baku kebisingan di daerah permukiman adalah $55 \mathrm{~dB}$ dan di daerah perdagangan jasa adalah sebesar 70 $\mathrm{dB}$. Rata-rata kecepatan angin tertinggi $\left(1,08 \mathrm{~m} \cdot \mathrm{s}^{-1}\right)$ ditemukan di jalan kolektor dan kecepatan angin terendah $\left(0,36 \mathrm{~m} . \mathrm{s}^{-1}\right)$ di jalan lokal. Data ini me-

Tabel 1 Rata-rata iklim mikro di jalan kolektor dan jalan lokal pada tiga tingkat naungan yang berbeda

\begin{tabular}{|c|c|c|c|c|c|c|c|c|}
\hline Perlakuan & $\begin{array}{c}\text { Intensitas } \\
\text { cahaya } \\
\text { (lux) }\end{array}$ & $\begin{array}{c}\text { Suhu } \\
\text { udara }\left({ }^{\circ} \mathrm{C}\right)\end{array}$ & $\begin{array}{c}\text { Kelembapan } \\
(\mathrm{RH})\end{array}$ & $\begin{array}{c}\text { Suhu } \\
\operatorname{tanah}\left({ }^{\circ} \mathrm{C}\right)\end{array}$ & $\begin{array}{c}\text { Kadar } \\
\text { lengas (\%) }\end{array}$ & $\begin{array}{l}\text { Kecepatan } \\
\text { angin }\left(\mathrm{m} \cdot \mathrm{s}^{-1}\right)\end{array}$ & $\begin{array}{l}\text { Kebisingan } \\
\text { (dB) }\end{array}$ & $\begin{array}{c}\text { Jumlah } \\
\text { kendaraan } \\
\text { (unit.menit }^{-1} \text { ) }\end{array}$ \\
\hline \multicolumn{9}{|l|}{ Jalan } \\
\hline Kolektor & $12184,18^{p}$ & $30,93^{p}$ & $71,74^{p}$ & $26,79^{p}$ & $50,09^{p}$ & $1,08^{p}$ & $74,34^{p}$ & $65^{p}$ \\
\hline Lokal & $11857,87^{p}$ & $31,01^{p}$ & $71,64^{p}$ & $26,81^{p}$ & $45,20^{p}$ & $0,36^{q}$ & 62,029 & $5^{9}$ \\
\hline \multicolumn{9}{|l|}{$\begin{array}{l}\text { Naungan } \\
\text { kanopi }\end{array}$} \\
\hline$>50 \%$ & $3095,59^{c}$ & $30,70^{b}$ & $71,83^{a}$ & $26,20^{c}$ & $48,64^{a}$ & $0,78^{a}$ & $68,16^{a}$ & $32^{a}$ \\
\hline $20-50 \%$ & $12677,72^{b}$ & $31,04^{a}$ & $71,59^{a}$ & $26,70^{b}$ & $47,70^{a}$ & $0,64^{a}$ & $69,14^{a}$ & $35^{a}$ \\
\hline $0 \%$ & $20289,77^{a}$ & $31,17^{a}$ & $71,50^{a}$ & $27,51^{a}$ & $46,60^{a}$ & $0,74^{a}$ & $67,24^{a}$ & $38^{a}$ \\
\hline Cv (\%) & 11,82 & 0,80 & 0,88 & 1,18 & 0,43 & 25,42 & 2,67 & 17,97 \\
\hline
\end{tabular}
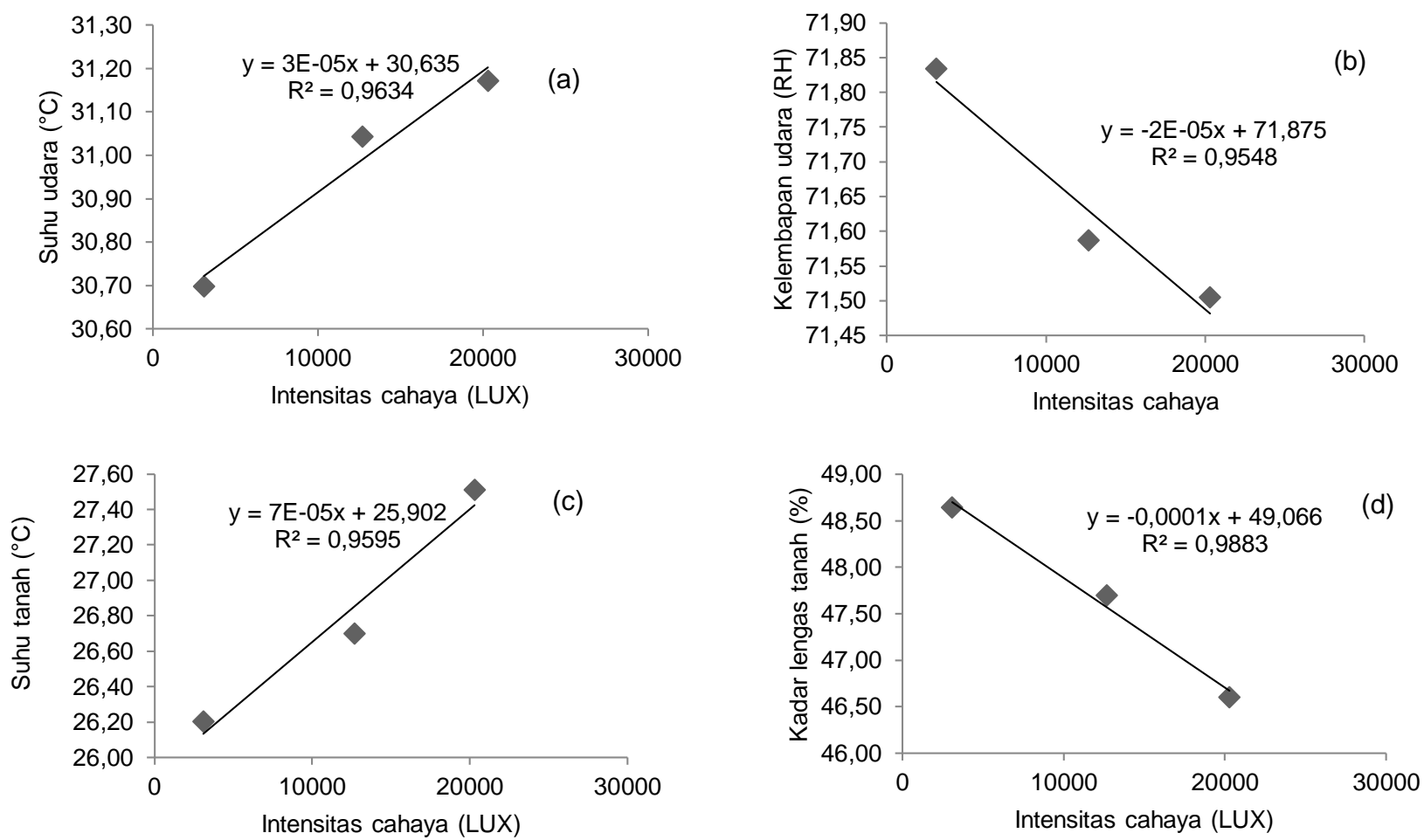

Gambar 6 a) Hubungan antara intensitas cahaya dan suhu udara; b) Kelembapan udara, c) Suhu tanah, dan d) Kadar lengas tanah. 
nunjukkan bahwa terdapat hubungan linear positif antara jumlah kendaraan dan kebisingan dan kecepatan angin di dua jenis jalan tersebut. Peningkatan kebisingan dan kecepatan angin dipengaruhi oleh jumlah kendaraan, masing-masing dengan persamaan $y_{\text {kebisingan }}=0,206 x_{\text {jumlah }}$ kendaraan $+60,982$ dan $y_{\text {kecepatan }}$ angin $=0,0119 x_{\text {jumlah kendaraan }}+0,3023($ Gambar 7$)$.

\section{Pertumbuhan Vegetatif Tanaman}

Pertumbuhan tanaman widelia di jalan kolektor dan jalan lokal (Tabel 2) tidak menunjukkan perbedaan nyata pada semua parameter pertumbuhan yang diukur. Hal tersebut membuktikan bahwa tanaman widelia memiliki pertumbuhan yang sama baiknya di kedua jenis jalan tersebut sehingga tanaman widelia dapat berpotensi sebagai tanaman jalur hijau di jalan kolektor maupun di jalan lokal di perkotaan. Berbeda dari hasil analisis ragam pertumbuhan tanaman pada tingkat naungan kanopi pohon, hasil analisis ragam menunjukkan perbedaan yang nyata pada panjang stolon, jumlah tunas, jumlah daun, jumlah ruas, dan bobot kering total. Tanaman widelia menunjukkan ratarata terendah pada tingkat naungan kanopi pohon penuh ( $>50 \%$ ), yaitu panjang stolon $96,97 \mathrm{~cm}, 102,02$ tunas, 137,00 daun, 16,33 ruas, dan $6,19 \mathrm{~g}$ bobot kering total. Sementara itu, pada tingkat naungan kanopi pohon sedang (20-50\%) dan tanpa naungan/ terbuka $(0 \%)$ menunjukkan hasil pertumbuhan yang sama. Pertumbuhan tanaman widelia (Wedelia Trilobata (L) Hitchc) menunjukkan respons parameter pertumbuhan yang sama dengan tanaman peony herba (Paeonia lactiflora Pall) (Zhao et al. 2012; Si et al. 2014).

Hasil analisis ragam pada Tabel 3 menunjukkan bahwa luas daun berpengaruh pada penangkapan cahaya matahari yang berperan dalam proses fotosintesis, dan hasil fotosintat akan ditransfer ke semua bagian tanaman untuk meningkatkan pertumbuhan dan perkembangan tanaman. Analisis ragam menunjukkan bahwa luas daun pada tingkat naungan
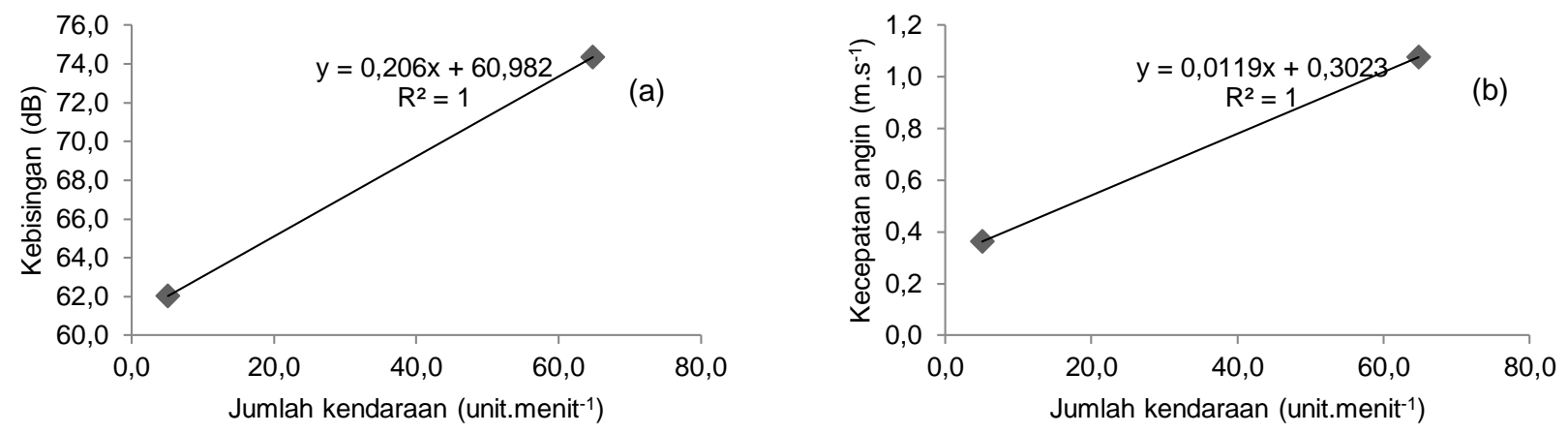

Gambar 7 a) Hubungan antara jumlah kendaraan dan kebisingan dan b) Kecepatan angin.

Tabel 2 Analisis ragam pertumbuhan tanaman widelia pada tiga tingkat naungan di jalan kolektor dan jalan lokal

\begin{tabular}{|c|c|c|c|c|c|}
\hline Perlakuan & Panjang stolon (cm) & Jumlah tunas & Jumlah daun & Jumlah ruas & Bobot kering total $(\mathrm{g})$ \\
\hline \multicolumn{6}{|l|}{ Jalan } \\
\hline Kolektor & $149,61^{p}$ & $155,06^{p}$ & $189,22 p$ & $19,89 p$ & $15,31^{p}$ \\
\hline Lokal & $143,42 p$ & $150,69 p$ & $214,44 p$ & $18,00 \mathrm{p}$ & $14,88^{p}$ \\
\hline \multicolumn{6}{|c|}{ Naungan kanopi } \\
\hline$>50 \%$ & $96.97 \mathrm{~b}$ & $102,02 \mathrm{~b}$ & $137,00 \mathrm{~b}$ & $16,33 \mathrm{~b}$ & $6,19 \mathrm{~b}$ \\
\hline $20-50 \%$ & 172.62 a & 179,43 a & 237,33 a & 19,83 a & $17,58^{a}$ \\
\hline $0 \%$ & $169.97^{a}$ & $177,17^{a}$ & 231,17 a & 20,67 a & 21,52 a \\
\hline $\mathrm{Cv}(\%)$ & 11,82 & 10,74 & $15,67^{*}$ & 11,87 & $10,64^{*}$ \\
\hline
\end{tabular}

Keterangan: Angka yang diikuti huruf yang sama pada kolom yang sama menunjukkan hasil yang tidak berbeda nyata berdasarkan DMRT pada $\alpha=5 \%$. ( $\left.{ }^{*}\right)$ data trasformasi $\sqrt{x+0,5}$

Tabel 3. Analisis ragam pertumbuhan luas daun (LD), bobot daun khas (BDK), laju asimilasi bersih (LAB), dan laju pertumbuhan (LPN) tanaman widelia pada tingkat naungan di jalan kolektor dan jalan lokal

\begin{tabular}{|c|c|c|c|c|}
\hline Perlakuan & LD (cm) & $\operatorname{BDK}\left(\mathrm{cm}^{2} \cdot \mathrm{g}^{-1}\right)$ & LAB (g. dm $^{2} \cdot$ ming $\left.^{-1}\right)$ & $\operatorname{LPN}\left(\mathrm{g}^{-1} \cdot \mathrm{g}^{-1} \cdot \mathrm{ming}^{-1}\right)$ \\
\hline \multicolumn{5}{|l|}{ Jalan } \\
\hline Kolektor & $1229,10^{p}$ & $0,004 p$ & $0,002 p$ & $0,220 p$ \\
\hline Lokal & $1119,07 \mathrm{p}$ & $0,005 p$ & $0,002 p$ & $0,195 \mathrm{p}$ \\
\hline \multicolumn{5}{|l|}{ Naungan kanopi } \\
\hline$>50 \%$ & 967,22 a & $0,003^{b}$ & $0,001^{a}$ & 0,207 a \\
\hline $20-50 \%$ & 1281,67 a & 0,004 a & 0,002 a & $0,204 a$ \\
\hline $0 \%$ & $1273,37 \mathrm{a}$ & $0,005^{a}$ & $0,003^{a}$ & $0,211^{a}$ \\
\hline Cv (\%) & $12,64^{*}$ & 19,020 & $0,12^{*}$ & $7,25^{\star}$ \\
\hline
\end{tabular}

Keterangan: Angka yang diikuti huruf yang sama pada kolom yang sama menunjukkan hasil yang tidak berbeda nyata berdasarkan DMRT pada $\alpha=5 \%$. ( $\left.{ }^{*}\right)$ data trasformasi $\sqrt{x+0,5}$. 
kanopi pohon penuh ( $>50 \%)$, sedang $(20-50 \%)$, dan tanpa naungan/terbuka (0\%) tidak menunjukkan perbedaan secara nyata. Hasil yang sama juga ditunjukkan pada parameter laju asimilasi bersih dan laju pertumbuhan nisbi tanaman. Hasil ini bebeda dari hasil analisis bobot daun khas (BDK) bahwa tingkat naungan kanopi pohon $>50 \%$ menurunkan BDK widelia secara nyata. Data bobot daun khas terendah pada tingkat naungan kanopi pohon penuh $(>50 \%)$ ialah $0,003 \mathrm{~cm}^{2} \cdot \mathrm{g}^{-1}$, tertinggi pada tingkat naungan kanopi pohon sedang (20-50\%) yang tidak berbeda nyata dibandingkan dengan BDK pada tanpa naungan/terbuka (0\%). Hal ini ditunjukkan bahwa tanaman widelia pada tingkat naungan kanopi pohon penuh $(>50 \%)$ memiliki ketebalan daun yang tipis (Miralles et al. 2011).

\section{Pengaruh Intensitas Cahaya pada Pertumbuhan Tanaman}

Cahaya matahari dibutuhkan tanaman untuk proses fotosintesis dan hasil pertumbuhan tanaman dinyatakan dalam bentuk bobot kering tanaman. Intensitas cahaya rendah akan menghambat pertumbuhan dan perkembangan tanaman. Tingkat naungan kanopi pohon penuh $(>50 \%)$ mengakibatkan intensitas cahaya yang rendah yang diterima oleh tanaman. Gambar 8 menunjukkan bahwa cahaya matahari menunjukkan hubungan linear positif dengan bobot kering tanaman. Hal tersebut mengartikan bahwa kenaikan bobot kering tanaman $96 \%$ dipengaruhi oleh intensitas cahaya matahari. Peningkatan intensitas cahaya sebesar 0,0009 lux akan meningkatkan bobot kering tanaman sebanyak $1 \mathrm{~g}$. Miralles et al. (2011) menyatakan hal yang sama pada tanaman Ramnus alaternus yang terpapar cahaya matahari penuh menunjukkan bobot kering yang lebih tinggi dibandingkan dengan tanaman yang ternaungi, begitu pula dengan pernyataan Hendriawan et al. (2016) pada tanaman kedelai. Perbedaan visual pertumbuhan tanaman widelia dapat dilihat pada Gambar 9 dan Gambar 10.

\section{KESIMPULAN}

Kondisi iklim mikro di jalan kolektor dan jalan local dua jalan menunjukkan bahwa intensitas cahaya tinggi menyebabkan suhu udara tinggi sehingga menurunkan kelembapan udara dan suhu tanah yang berakibat pada penurunan kadar lengas tanah. Peningkatan jumlah kendaraan mengakibatkan peningkatan kecepatan angin dan kebisingan. Widelia dapat tumbuh baik pada berbagai tingkat naungan, baik di jalan kolektor maupun jalan lokal. Namun, pada tingkat naungan kanopi pohon penuh ( $>50 \%)$ menunjukkan

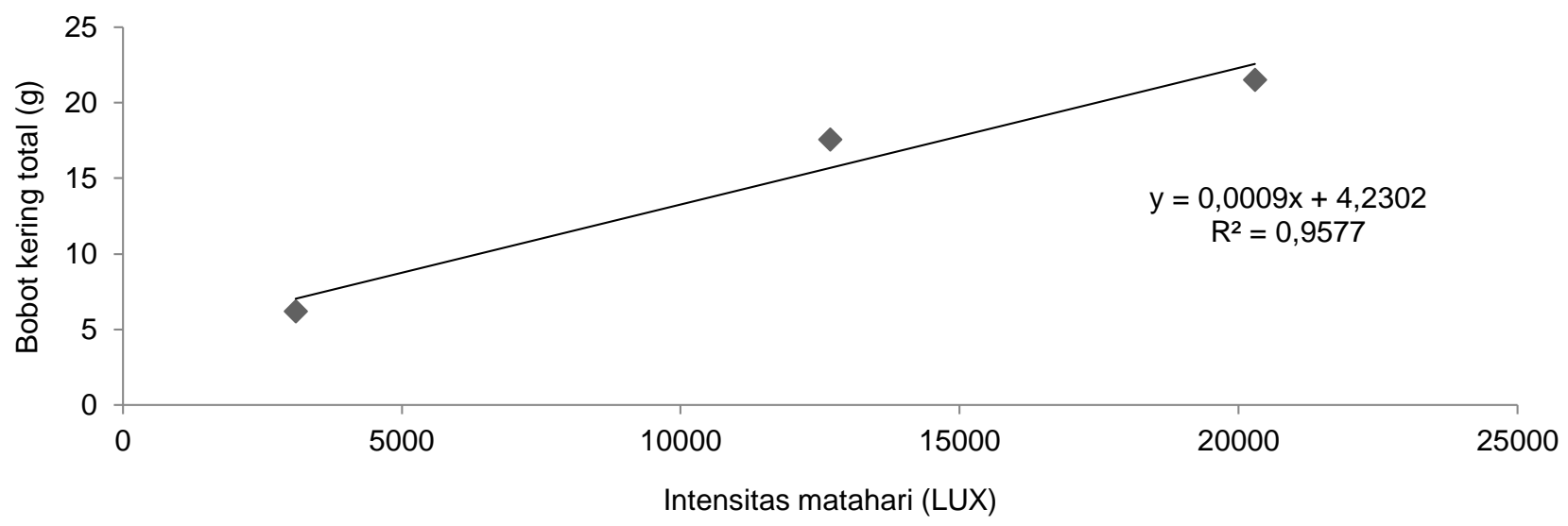

Gambar 8 Persamaan linear intensitas cahaya dengan bobot kering tanaman.
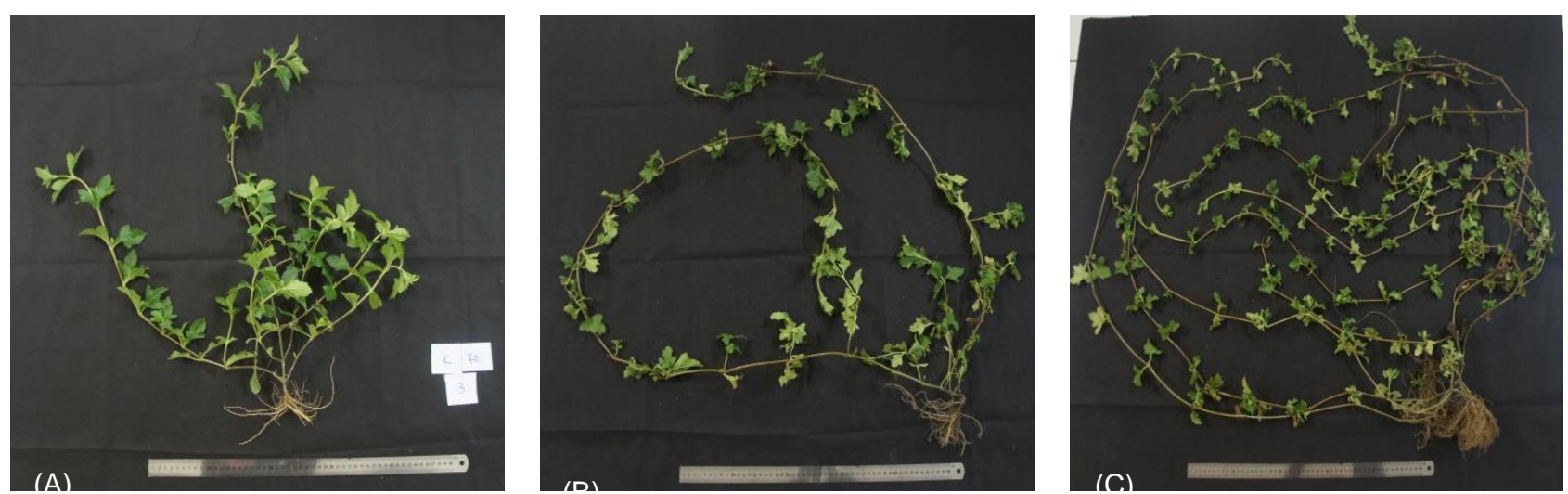

Gambar 9 Perbedaan visual tanaman widelia di jalan kolektor umur 12 minggu setelah tanam: A) Naungan kanopi pohon penuh (>50\%) bobot kering 7,56 g; B) sedang (20-50\%) bobot kering 19,52 g; dan C) tanpa naungan/terbuka $(0 \%)$ bobot kering $36,60 \mathrm{~g}$. 

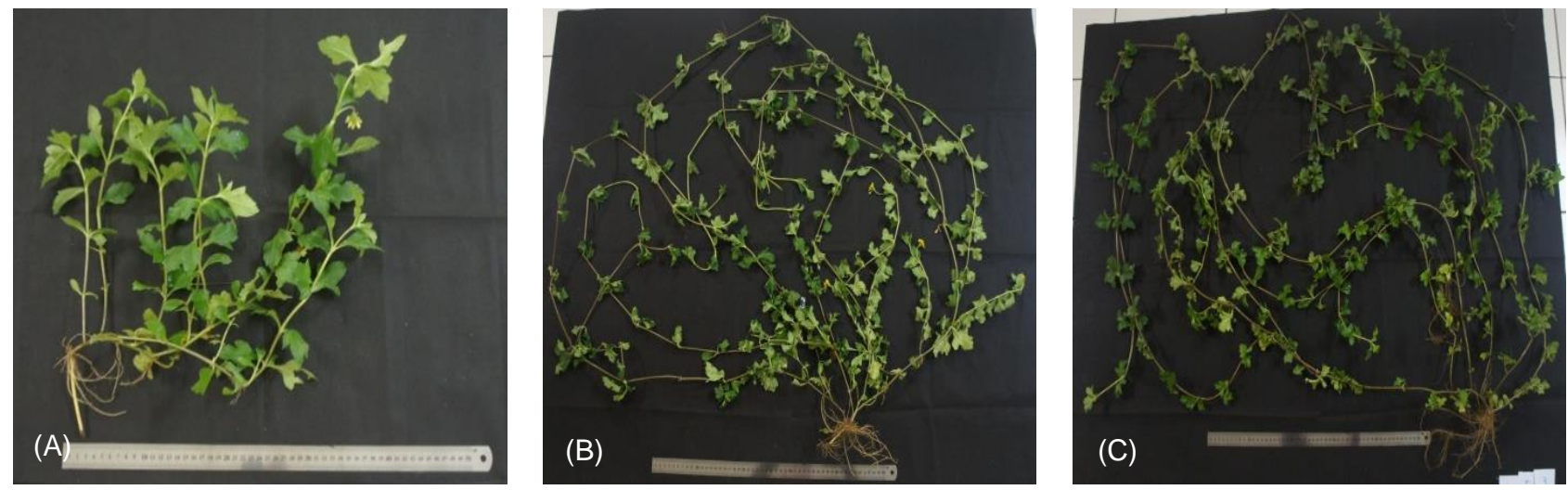

Gambar 10 Perbedaan visual tanaman widelia di jalan lokal umur 12 minggu setelah tanam: A) Naungan kanopi pohon penuh $(>50 \%)$ bobot kering 4,12 g; B) Sedang (20-50\%) bobot kering 31,38 g; dan C) Tanpa naungan/terbuka (0\%) bobot kering $36,47 \mathrm{~g}$.

pertumbuhan widelia yang paling rendah dibandingkan dengan pada tingkat naungan kanopi pohon sedang (20-50\%) dan tanpa naungan/terbuka (0\%). Berdasarkan hal ini widelia direkomendasikan untuk penghijauan jalan kota.

\section{DAFTAR PUSTAKA}

[BLH] Badan Lingkungan Hidup. 2018. Data Sebaran Ruang Terbuka Hijau di DIY. [internet]. [diunduh 10 Maret 2018]. Tersedia pada: http://blh.jogjaprov. go.id/pages/ragam-data

[BPS] Badan Pusat Statistik. 2018. Provinsi Daerah Istimewa Yogyakarta Dalam Angka Daerah Istimewa Yogyakarta Province in Figures. Yogyakarta (ID).

Buyadi SNA, Mohd WMNW, Misni A. 2013. Green Spaces Growth Impact On The urban Microclimate. Social and Bihavioral Sciences. 105: 547-557. https://doi.org/10.1016/j.sbspro.2013.11.058

[CTAHR] College of Tropical Agriculture \& Human Resources. 1997. Wedelia (Oernamentals and Flowers OF-2). Universcity of hawai at Manoa.

Du H, Cai W, Xu Y, Wang Z, Wang Y, Cai Y. 2017. Quantifying the cool island effect of urban green spaces using remote sensing data. Urban forestry and Urban Greening. 27: 24-31. https://doi.org/ 10.1016/j.ufug.2017.06.008

Hendriawan A, Respatie DW, Thohari. 2016. Pengaruh Intensitas Naungan terhadap Pertumbuhan dan Hasil Tiga Kultivar Kedelai (Glycine max (L) Merrill) di Lahan Pasir Pantai Bugel, Kulon Progo. Vegetalika. 5(3): 1-14.

Gardner FP, Pearce RB, Michell RL. 1991. Fisiologi tanaman budidaya. H. Susilo, Subiyanto. Jakarta (ID): Penerbit universitas Indonesia.

Gilman EF. 1999. Wedelia Trilobata wedelia. UF/IFAS Extention University of Florida. [internet] [diakses 10
Maret 2018]. Tersedia pada: https://edis. ifas.ufl.edu/pdffiles/FP/FP61200.pdf.

Keputusan Menteri Negara Lingkungan hidup No. KEP-48/MENLH/11/1996 Tentang Baku Tingkat Kebisingan [internet]. [diunduh 16 Desember 2019]. Tersedia pada. http://www.cets-uii.org/BML/ Kebisingan/kepmen4896.

Miralles J, Martinez-sanchez JJ, Franco JA, Banon S. 2011. Ramus alaternus under four simulated shade enviriments morphological, anatimica and physiological responsses. Scientia horticulturae. 127: 562-570. https://doi.org/10.1016/j.scienta. 2010.12.005

Miswati. 2017. Pengaruh naungan terhadap pertumbuhan, kerapatan trikomadan kandungan flafonoidtotal daun tanaman kumis kucing (Orthosiphon stamineus Benth). [Skripsi]. Yogyakarta (ID): Universitas Gadjah Mada.

Peraturan Pemerintah Republik Indonesia Nomor 34 Tahun 2006 Tentang Jalan. [internet] [diunduh 31 Desember 2018]. Tersedia pada https://www. hukumonline.com/pusatdata/download/fl48203/nod e/25773

Saleha A, Alimuddin, Gunawan R. 2013. Distribusi Logam Timbal $(\mathrm{Pb})$ pada Tanaman Widelia (Wedelia trilobata (L.) Hitchc) Akibat Emisi Kendaraan Bermotor Dibeberapa Jalan Kota Samarinda. Jurnal Kimia Mulawarman. 10(2): 8084

Si CC, Dai Z, Lin Y, Qi S, Huang P, Miao S, Du D. 2014. Local Adaptation and Phenotypic plasticity both Occurred in Wedelia trilobata invation across a tropical island. Biological Invations. 16(2014): 2323-2337. https://doi.org/10.1007/s10530-0140667-4

Singapore Goverment. 2018. National Parks Flora \& Fauna Web. National parks. [internet]. [diakses 23 November 2018]. Tersedia pada: https:// florafaunaweb.nparks.gov.sg. 
Thaman RR. 1999. Wedelia trilobata : Daisy Invader Of The Pasific Islands. IAS Tecknical Report 99/2. Institute of Applied Science. Universuty of the South Pasific Suva. Fiji Islands.

Wahyunah, Krisdianto A. Kadarsah, Rahman dr. 2016. Variasi kanopi dan porositas pohon diruang pribadi permukiman baru kelirahan loktabat utara kota banjarbaru. Jukung Jurnal Teknik Lingkungan. 2(2): 61-67.

Zhao D, Hao Z, Tao J. 2012. Effect of shade on plane growth and flower quality in the herbaceous peony (Paeonia lactiflora Pall.). Plant Physiology and Biochemistry. 61: 186-196. https://doi.org/10.1016/ j.plaphy.2012.10.005 